\title{
BMJ \\ Child health: what should be done?
} Paediatrics Open

To cite: Choonara I. Child health: what should be done? BMJ Paediatrics Open 2017;1:e000001. doi:10.1136/ bmjpo-2017-000001

Received 7 March 2017 Revised 19 March 2017 Accepted 24 March 2017

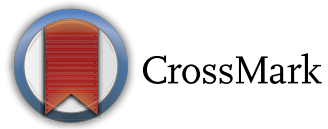

Medical School (Derby), University of Nottingham Schoo of Medicine, Derby, UK

Correspondence to Emeritus Professor Imti Choonara, Medical School (Derby), University of Nottingham School of Medicine, Derby, DE22 3DT, UK.; Imti. Choonara@nottingham.ac.uk
Over 17000 children under the age of 5 years die every day. ${ }^{1}$ The majority of these children die in either sub-Saharan Africa or South Asia. Most of these children die from preventable causes, including gastroenteritis, pneumonia and malaria. Progress has been made in reducing child mortality with a $50 \%$ reduction in under five mortality between 1990 and 2013. ${ }^{1}$ This was however less than the two-thirds reduction target in the Millennium Development Goals. Although the majority of deaths occur in low-income and middle-income countries, there are wide disparities in child mortality between high-income countries. Child mortality rates in the UK are higher than in many other European countries. ${ }^{2}$ Similarly, the USA has higher child mortality rates than neighbouring Canada and Cuba. ${ }^{1}$ Additionally within countries, there are wide disparities in child mortality. The poorest, most deprived sections of the community have the highest child mortality rates. The new United Nations Sustainable Development Goals (SDGs) include the reduction of poverty and inequalities as they recognise the link between socioeconomic factors and health.

\section{SOLUTIONS}

The evidence base for ensuring children are healthy is quite extensive. Politicians and governments are aware that the following are key contributors to ensuring that children are healthy. They are all included within the SDGs.

- Universal healthcare: In 1948, Aneurin Bevan, who was then Minister of Health, launched the National Health Service (NHS) in the UK. It was based on three core principles: (i) it would be free at the point of delivery; (ii) it would be available to everybody, that is, universal; and (iii) that it would be financed entirely from taxation, that is, it was a government responsibility that people would pay into it according to their means. Despite recent cutbacks and privatisation of services, the NHS has been an excellent blueprint for other countries to emulate. One of the SDGs is universal health coverage by 2030 . This includes financial risk protection, access to healthcare and safe, effective and affordable essential medicines and vaccines for all.

- Universal education: Universal education is essential in its own right. It is however crucial for good health. Education is a prerequisite for effective health prevention strategies and combating stigma which affects adherence to medication for many chronic illnesses.

- Adequate nutrition: Worldwide, more than one in eight children are underweight and one in four children have stunted growth. Malnourished children are more susceptible to infectious diseases. Malnutrition in pregnant women is more likely to result in a low-birthweight infant, who are at risk of increased mortality, especially in the first year of life.

Access to clean water and adequate sanitation facilities: Access to clean water and sanitation are important in relation to gastrointestinal diseases. Countries with poor sanitation, especially in rural areas, have high child mortality rates. ${ }^{1}$ Less than half of the world's population in rural areas have access to improved sanitation facilities.

- Universal immunisation: Immunisation has played a crucial role in the reduction of child deaths from many infectious diseases. Unfortunately, more than one in eight infants worldwide remain unimmunised against tetanus. ${ }^{1}$

\section{HOW GOVERNMENTS SPEND MONEY}

Governments may choose not to spend money on health, education and providing essential services. They will often state there is not enough money. It is disappointing that 24 countries spent more on military expenditure than on health. ${ }^{1}$ Many of these countries have high child mortality rates. Each year in India, over a million young children under the age of 5 years die. Despite this, their government, like 23 others, prefer to spend more money 
on military expenditure than on healthcare. ${ }^{1}$ Even the USA, which has the largest military budget in the world (US $\$ 597$ billion in 2015) spends more on health. A weakness of the SDGs is that they do not call for a reduction in military expenditure.

Inequalities are a major problem in societies. Inequalities also affect child health and child mortality. The major financial institutions have promoted austerity as the way forward following the financial crisis in 2008 precipitated by their own actions. In contrast, both Iceland and Cuba have shown that child health can be preserved in the poorest, least fortunate sections of society by preserving universal services in health, education and social welfare. ${ }^{3}$ Iceland has the lowest under five mortality rates in the world. This is despite a major economic crisis. It illustrates how governments can choose to save children's lives by protecting essential services. It is therefore disappointing that despite the overwhelming evidence, successive governments in the UK continue to cut essential services.

\section{CAN A NEW JOURNAL HELP?}

The Royal College of Paediatrics and Child Health (RCPCH) has a proud and long-standing record of highlighting the problems experienced by children in the UK, both in relation to physical and mental health. ${ }^{4}$ It has also contributed internationally to promote child health, both in specific projects and through its journal Archives of Disease in Childhood. Although a highly successful journal, it is however a subscription only journal and hence is not available to many health professionals throughout the world. There is a growing recognition that open-access publishing is more beneficial for science and clinical research. ${ }^{5}$ BMJ Publishing and the RCPCH have an established track record with Archives of Disease in Childhood and have established BMJ Paediatrics Open in recognition of the need for a paediatric open access journal.

Like the RCPCH, the journal will be a strong advocate for children's health, both within the UK and overseas. Health professionals not only have the right to act on behalf of children, they have a responsibility to try and ensure that children have the best possible health outcomes. Unlike Archives of Disease in Childhood and many other journals, we will publish all ethically and scientifically sound research in relation to child health.

- We will not reject articles on grounds of priority as we feel it is important that health professionals decide whether the scientific content is important or not.
We will endeavour to process articles as rapidly as possible.

- The peer review process will be transparent in that all peer reviewers are obliged to provide their name.

\section{LOW-INCOME COUNTRIES}

We recognise that we are competing against established journals but hope to show that BMJ Paediatrics Open will contribute to the provision of scientific medical information in relation to child health. We are an international journal and in particular welcome papers from health professionals in low-income countries. We are delighted to confirm that authors from low-income countries will not be charged an article processing charge in keeping with the Health InterNetwork Access to Research Initiative (HINARI) guidelines. We also welcome research in the neglected diseases that disproportionally affect children in low-income and lower-middle-income countries.

Our aim is quite simple. We wish to publish scientific research and clinical review articles that educate and help health professionals in their clinical practice. Scientific information needs to be available to all health professionals in order to ensure that they arrange appropriate investigations, make the correct diagnosis and give the correct treatment to each patient that they see. ${ }^{5}$ We hope for improved child health outcomes but we recognise that the major factors affecting child health and death are socioeconomic and political. We will therefore act as an advocate for child health as a human right.

Competing interests None declared.

Provenance and peer review Commissioned; externally peer reviewed.

Open Access This is an Open Access article distributed in accordance with the Creative Commons Attribution Non Commercial (CC BY-NC 4.0) license, which permits others to distribute, remix, adapt, build upon this work non-commercially, and license their derivative works on different terms, provided the original work is properly cited and the use is non-commercial. See: http://creativecommons.org/ licenses/by-nc/4.0/

(C) Article author(s) (or their employer(s) unless otherwise stated in the text of the article) 2017. All rights reserved. No commercial use is permitted unless otherwise expressly granted.

\section{REFERENCES}

1. UNICEF. The State of the World's Children 2015. Reimagine the future: innovation for every child: New York, NY: UNICEF, 2015.

2. Tambe P, Sammons HM, Choonara I. Why do young children die in the UK? A comparison with Sweden. Arch Dis Child 2015;100:928-31.

3. Gunnlaugsson G. Child health in Iceland before and after the economic collapse in 2008. Arch Dis Child 2016;101:489-96.

4. RCPCH. State of Child Health: 2017 recommendations for England. London: RCPCH , 2017.

5. Bhaumik S, Pakenham-Walsh N, Chatterjee P, et al. Governments are legally obliged to ensure adequate access to health information. Lancet Glob Health 2013;1:e129-30. 